\title{
A New Approach of a Specific Sustainability Model
}

\section{Corneliu Bob*}

Department of Civil Engineering, Politehnica University of Timișoara, Romania

\begin{abstract}
The paper presents a new approach for obtained the sustainability of the construction works. In the technical literature there are a lot of models which evaluate the sustainability performance of the construction works with high applicability and very comprehensive. In many cases such models show some disadvantage: some models do not cover all three dimensions of the sustainability; all of them include a great number of criteria and many of them are difficult or impossible to quantify; they are focused manly on entire buildings and they can be applied with some difficulties on other types of construction works and activities. The first step to avoid such disadvantages was by proposal a so called specific model with some advantages: high degree of utilization includes only quantitative parameters, covers the three dimensions of sustainability. The second step is presented in this paper by a new approach which takes into account the price of each parameter and finally, the sustainability cost is established. The application of new model is presented on three different construction works. Using of the new approach some advantages are obtained: such calculation is easy understandably by specialists; by using the correction of the mechanical characteristics the most sustainable solution is obtained: costs of main parameters where taken from Romanian practice, but for different zones and countries, such costs will have to be used.
\end{abstract}

Keywords: Sustainability; Specific building model; Sustainability index; Sustainability cost; Case studies

\section{Introduction}

Most of the existing models which evaluate the sustainability performances of construction works are very comprehensive and with high applicability, like: BREEM [1], LEED [2], DGNB [3], CASBEE [4], SB Tool [5], Green Star [6], HK-BEAM [7] and so on.

On the other hand, ISO [8-10] establishes a set of indicators to take into account the use and development of sustainability indicators for assessing the sustainability performance of new or existing buildings related to this design, construction, operation, maintenance, refurbishment and end of the live. EN 15643-1 provides the general principles and requirements, expressed through a series of standards, for the assessment of buildings in terms of environmental, social and economic performance taking into account technical characteristics and functionality of a building $[11,12]$.

In many cases such models show some disadvantages: Any of models do not cover all three dimensions; they include a great number of criteria and many of them are difficult or impossible to quantify; the tools are focused manly on entire buildings and they can be applied with some difficulties on other types of construction works and activities.

To avoid disadvantages, the author and his collaborators had proposed a new assessment method, called specific model. The main advantages of this method are: covers the three dimensions of sustainability; high degree of applicability; includes only quantitative parameters. The new approach, presented in this paper, is based on the specific model but instead of the calculation of the sustainability index SI the evaluation takes into account the price of each parameter of the tree dimensions and finally the sustainability cost SC is obtained.

\section{Specific model}

The specific model is based on simple mathematical equations, which combine the results of the quantified parameters in a rational way, obtaining finally a sustainability index SI:

$$
\begin{aligned}
& \mathrm{SI}=\mathrm{S}_{\mathrm{env}}+\mathrm{S}_{\mathrm{eco}}+\mathrm{S}_{\mathrm{soc}} \\
& \mathrm{S}_{\mathrm{env}}=\sum_{\mathrm{i}=1}^{\mathrm{n}} \alpha_{\mathrm{i}} \times \frac{\mathrm{P}_{\mathrm{i}, \mathrm{env}}^{\mathrm{R}}}{\mathrm{P}_{\mathrm{i}, \mathrm{env}}} ; \mathrm{S}_{\mathrm{eco}}=\sum_{\mathrm{i}=1}^{\mathrm{n}} \beta_{\mathrm{i}} \times \frac{\mathrm{P}_{\mathrm{i}, \mathrm{eco}}^{\mathrm{R}}}{\mathrm{P}_{\mathrm{i}, \mathrm{eco}}} ; \mathrm{S}_{\mathrm{soc}}=\sum_{\mathrm{i}=1}^{\mathrm{n}} \gamma_{\mathrm{i}} \times \frac{\mathrm{P}_{\mathrm{i}, \text { soc }}^{\mathrm{R}}}{\mathrm{P}_{\mathrm{i}, \mathrm{soc}}}
\end{aligned}
$$

Where:

\section{SI-Sustainability Index.}

$\mathrm{S}_{\text {env }}, \mathrm{S}_{\text {eco }}, \mathrm{S}_{\mathrm{soc}}-$ Sustainability indexes for the environmental, economic and social dimensions.

$\alpha_{i}, \beta_{i}, \gamma_{i}$ - Weighting factors of each parameter of the environmental, economic and social dimensions.

$\mathrm{P}_{i \text {, env }}^{\mathrm{R}}, \mathrm{P}_{i \text {, eco }}^{\mathrm{R}}, \mathrm{P}_{\mathrm{i} \text { soc }}^{\mathrm{R}}$ - Calculated value for each parameter.

$\mathrm{P}_{i \text { env }}^{\mathrm{R}}, \mathrm{P}_{\mathrm{i} \text { eco }}^{\mathrm{R}}, \mathrm{P}_{\mathrm{i} \text { soc }}^{\mathrm{R}}$ - Reference value for each parameter.

In case of a comparison between different solutions, the reference values can be taken as the best values of the parameters from each solution; in case of a self assessment the best available practices are taken as reference values. For those situations, where the higher value of a parameter is considered more sustainable, the ratios of these parameters in Equation (2) become $\mathrm{P}_{\mathrm{i}} / \mathrm{P}_{\mathrm{i}}^{\mathrm{R}}$ [13-15].

The final result of the developed specific model is a Sustainability Index SI, whit a dimensionless value between 0 and 1 , where 1 is the best and 0 is the worst value. Similar approach has been suggested by Grace [16] and Diaz - Balteiro and Romero [17], but there are some difficulties for application of the models.

\section{Sustainability cost}

The whole - life costing (WLC) models consist in determining the total cost of any infrastructure from its initial conception to the end of its service life [18]. WLC models use the NPV approach, presented by American Society for Testing and Materials [19], in which:

$$
\mathrm{NPV}=\mathrm{C}+\mathrm{R}-\mathrm{S}+\mathrm{A}+\mathrm{M}+\mathrm{E}
$$

where $\mathrm{C}=$ investment cost; $\mathrm{R}=$ replacement costs; $\mathrm{S}=$ resale value at the studied period; $A=$ annually recurring operating, maintenance and

${ }^{*}$ Corresponding author: Corneliu Bob, Department of Civil Engineering, Politehnica University of Timișoara, Piața Victoriei 2, Timișoara 300006, Romania, Tel: +40 256 403 000; E-mail: cbob@mail.dnttm.ro

Received May 03, 2017; Accepted June 01, 2018; Published June 05, 2018

Citation: Bob C (2018) A New Approach of a Specific Sustainability Model. J Civil Environ Eng 8: 314 doi: 10.4172/2165-784X.1000314

Copyright: $\odot 2018$ Bob C. This is an open-access article distributed under the terms of the Creative Commons Attribution License, which permits unrestricted use, distribution, and reproduction in any medium, provided the original author and source are credited. 
repair costs (except energy costs); $M=$ non-annually recurring operating, maintenance and repair costs (except energy costs); $\mathrm{E}=$ energy costs.

On the other hand, the EC has proposed "Sustainable Structural Design (SSD) methodology" which is based on three steps [20]:

Step I: Environmental Assessment (with the phases: Raw material Extraction, Manufacturing Production, Transportation, Utilization Reuse, Recycling and Energy plus Carbon emissions).

Step II: Structural Performance - Based Assessment (sPBA) method (with the phases: Definition of limit states, Structural Analysis, Hazard Analysis, Cost Analysis) and Repair costs plus Downtime losses.

Step III: Combination of environmental and structural results (with the phases: Carbon Emissions - tons $\mathrm{x} € /$ ton, Energy consumption kwh $\mathrm{x} € / \mathrm{kwh}$ plus L - Total Expected Loss=Repair Costs $€+$ Downtime loss $€$ which give Global Assessment parameter in $€$.

As it was pointed in the Introduction, such global models and the others have a lot of disadvantages. The simple approach of specific construction works sustainability cost is presented below. It has a larger applicability and can be use for: partial building works; production of building materials; rehabilitation works; transport of prefabricated elements; construction technologies etc.

$$
\mathrm{SC}=\mathrm{SC}_{\mathrm{env}}+\mathrm{SC}_{\mathrm{eco}}+\mathrm{SC}_{\text {soc }}
$$

In which:

$$
\mathrm{SC}_{\text {env }}=\sum_{\mathrm{i}=1}^{\mathrm{n}} \alpha_{\mathrm{i}} \cdot \mathrm{P}_{\mathrm{i}, \text { env }} ; \mathrm{SC}_{\text {eco }}=\sum_{\mathrm{i}=1}^{\mathrm{n}} \beta_{\mathrm{i}} \cdot \mathrm{P}_{\mathrm{i}, \text { eco }} ; \mathrm{SC}_{\mathrm{soc}}=\sum_{\mathrm{i}=1}^{\mathrm{n}} \gamma_{\mathrm{i}} \cdot \mathrm{P}_{\mathrm{i}, \text { soc }}
$$

Where:

SC - sustainability cost.

$\mathrm{SC}_{\text {env }}, \mathrm{SC}_{\text {eco }}, \mathrm{SC}_{\mathrm{soc}}$ - sustainability cost for environmental, economic and social dimensions.

$\alpha_{i}, \beta_{i}, \gamma_{i}$ - weighting factor of each parameter for environmental, economic and social dimensions.

$\mathrm{P}_{\mathrm{i} \text { env }}, \mathrm{P}_{\mathrm{i} \text { eco }}, \mathrm{P}_{\mathrm{i} \text { soc }}$ - calculated value for each parameter.

The Sustainability cost is the best for minimum value and the worst for the maximum value. For some parameters of the sustainability analysis $\mathrm{P}_{\mathrm{i} \text { env }}, \mathrm{P}_{\mathrm{i} \text { eco }}, \mathrm{P}_{\mathrm{i} \text { soc }}$, the prices are presented in Table 1.

In the case of embodied energy, GHG emissions, land use, water consumption and workload the cost in €/unit was taken from technical literature. There are possibilities to change such data in function of the geographical zone or country.

For the noise during construction, a simple formula for reduction in noise was used:

$$
\Delta \mathrm{L}=20 \log (\mathrm{m}), \quad[\mathrm{dB}]
$$

where: $\mathrm{m}$ - the surface mass of the protected wall, $\mathrm{kg} / \mathrm{m}^{2}$.

For the calculated value in Table 1 , a cell concrete of $0,1 \mathrm{~m}$. and a density of $600 \mathrm{~kg} / \mathrm{m}^{3}$ were used. For the protection measures in the case of dust control on construction site, a barrier is erected around dusty activities (about $1 € / \mathrm{m}^{2}$ ).

The cost of the mechanical characteristics (bending moment, stress and stiffness) were obtaining by calculating the influence of the increasing of the concrete class for stress, elasticity module for stiffness and cross area for bending moment. For a better appreciation of the mechanical characteristics contribution on the sustainability analysis a correction is necessary to be introduced:

$$
\mathrm{K}^{\mathrm{C}}=\mathrm{K}_{\mathrm{i}}^{\mathrm{C}} \frac{\mathrm{K}^{\mathrm{R}}}{\mathrm{K}_{\mathrm{i}}}
$$

Where, $K^{C}$ - the final value [€] of the stiffness; $K_{i}^{C}$ - the stiffness [ $€$ ] after strengthening; $K_{i}$ - the stiffness obtained after strengthening; $K^{R}$ the reference (maximum) value of the stiffness.

The same procedure is used for bending moment and stress too. Weighting factors for sustainability analysis are proposed to be:

$$
\alpha_{\mathrm{i}}=0.4 ; \beta_{\mathrm{i}}=0.3 ; \gamma_{\mathrm{i}}=0.3 \text {. }
$$

\section{Case Studies Review}

The specific model for obtaining the Building Sustainability Index as well as the Sustainability Cost is presented below.

\section{Rehabilitation of the Western University of Timisoara, Romania}

Different solutions have been proposed for the strengthening of the columns: coating whit steel profiles, reinforced concrete jacketing and composites based on CFRP (lamellas and sheets). Details of the solutions are presented in Figure 1 [21-23].

\begin{tabular}{|c|c|c|c|}
\hline \multicolumn{2}{|c|}{ Parameters } & \multirow{2}{*}{$\begin{array}{c}\text { Unit } \\
3\end{array}$} & \multirow{2}{*}{$\begin{array}{c}\text { Cost [€/unit] } \\
4\end{array}$} \\
\hline 1 & 2 & & \\
\hline \multirow{3}{*}{ Embodied energy and GHG emissions } & \multirow{2}{*}{ Energy } & MJ & 0.12 \\
\hline & & kwh & 0.035 \\
\hline & $\mathrm{CO}_{2}$ & $\mathrm{~kg}$ & 0.23 \\
\hline Land use and & Land use & $\mathrm{m}^{2}$ & 30 \\
\hline Water consumption & Water & $\mathrm{m}^{3}$ & 0.75 \\
\hline \multirow{2}{*}{ Dust and noise during construction } & Dust $^{*}$ & $\mathrm{~m}^{2}$ & 1 \\
\hline & Noise $^{* *}$ & $\mathrm{~dB}$ & 0.15 \\
\hline \multirow{3}{*}{ Mechanical characteristics } & Bending moment & $\mathrm{kNm}$ & 2.5 \\
\hline & Stress & $\mathrm{N} / \mathrm{mm}^{2}$ & 2.9 \\
\hline & Stiffness & $\mathrm{kNm}$ & 0.85 \\
\hline \multicolumn{2}{|c|}{ Workload } & man/hour & 10 \\
\hline
\end{tabular}

Analyzing the characteristics of the solutions, several parameters from each dimension of sustainability have been selected for evaluation, the ones which are, $\mathrm{CO}_{2}$ emissions arising from the manufacturing, transport and execution of the building materials, total cost, consolidated

Table 1: Some costs of main parameters. 


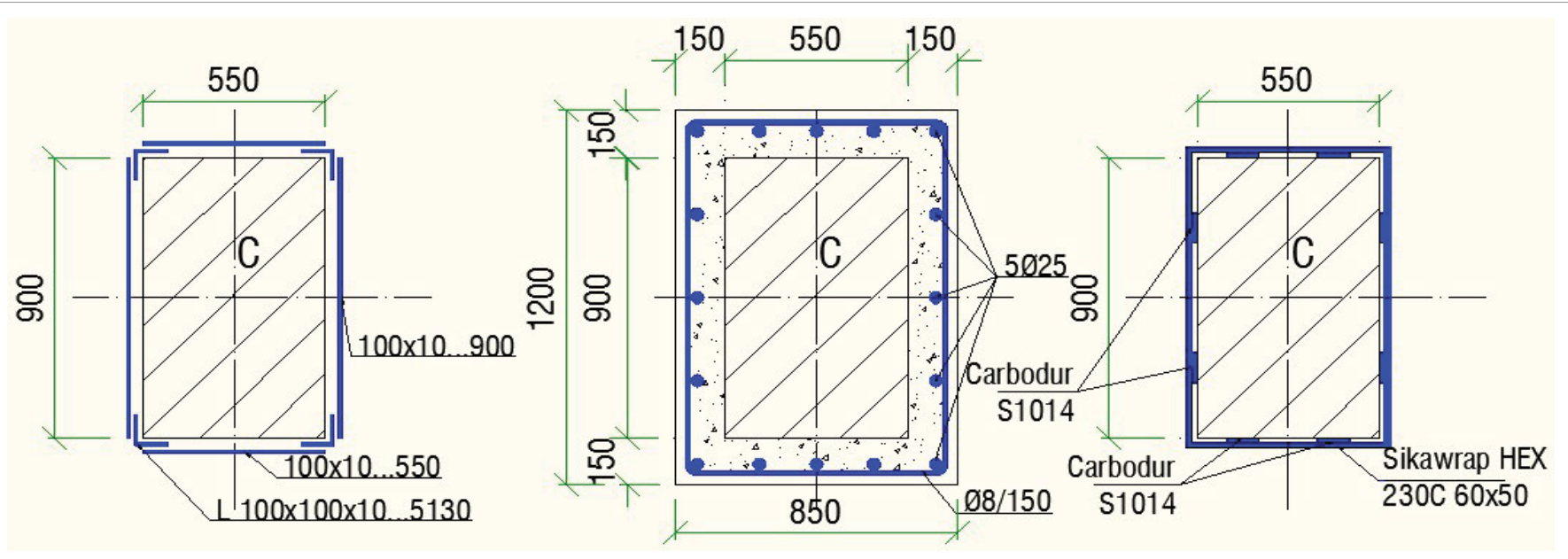

Figure 1: Strengthening solutions using steel profiles, RC jacketing and CFRP.

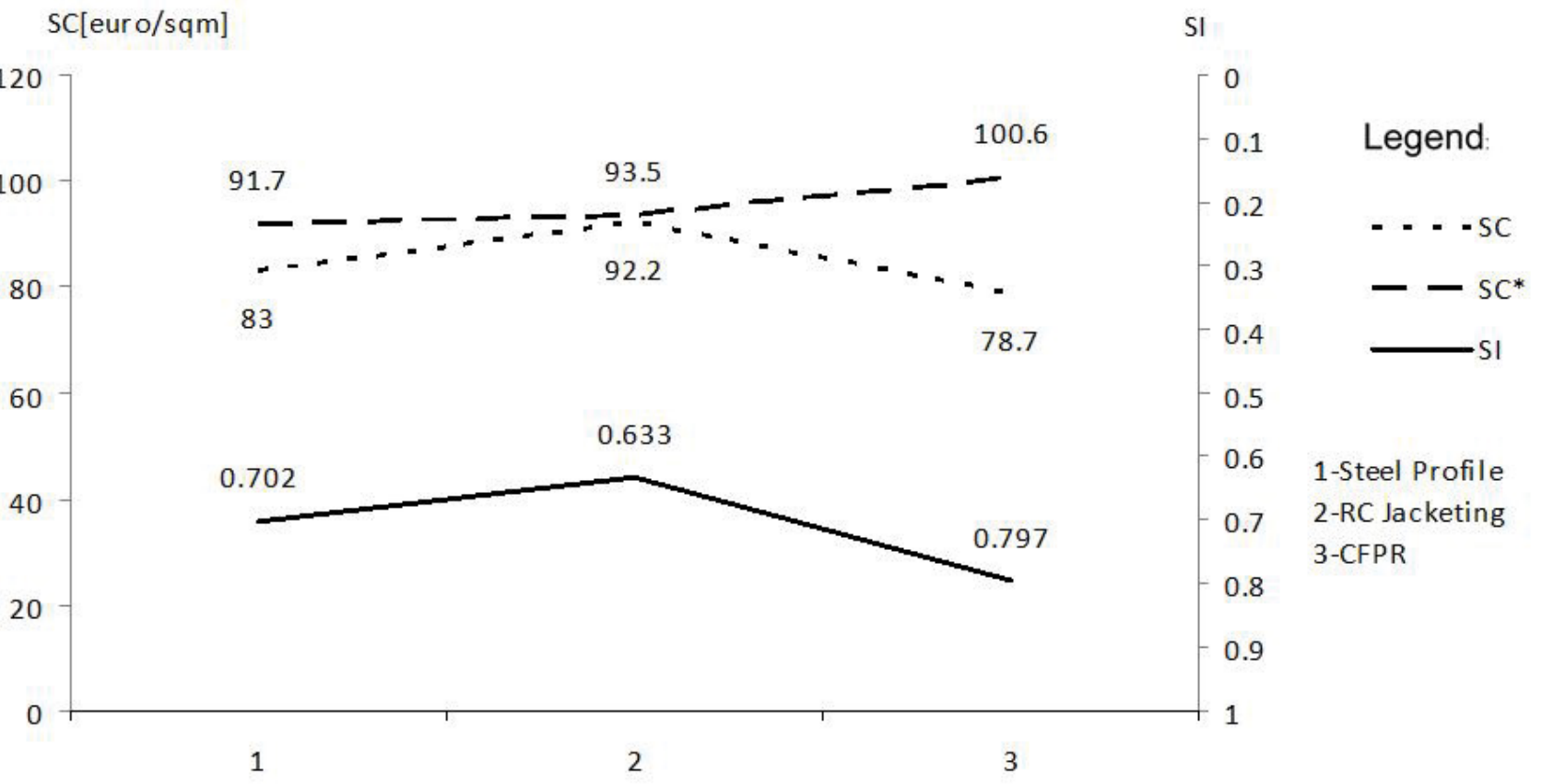

Figure 2: Sustainability for rehabilitation of the Western University.

time (workload), increase of the capable bending moment and stiffness of the consolidated element. To quantify the parameters, different databases, codes and bulletins have been used. The results of the analysis are presented in Table 2 and Figure 2.

For an easy observation, the sustainability index SI is presented from top to down and the sustainability cost SC from down to top in Figure 2. Before the correction of the mechanical characteristics the most sustainable solution proved to be the CFRP procedure for both sustainability index SI as well as for sustainability cost SC. After operating the correction, the most sustainable solution is by using steel profiles, which has been applied.

\section{Transport of prefabricated elements}

The aim of this example is to demonstrate the applicability of the specific model also on other types of construction activities. An industrial hall made of prefabricated reinforced concrete elements has to be transported from Timisoara to Galati $(690 \mathrm{~km}$ on road). The structure consists of 97 elements (beams and columns), weighting $450 \mathrm{t}$. Due to the great mass, four transport opportunities have been evaluated: on road by trucks, on railway by train, on inland water Danube River) by barge and a combined solution by truck and barge, because in many situations there is no direct access on inland water (like in case of Timisoara) [23,24].

For the sustainability evaluation of each transport method, different parameters have been assessed. The most important were the $\mathrm{CO}_{2}$ emissions, costs, transport duration, emissions of dust and noise. For transport of prefabricated RC elements, the results of the analysis are presented in Table 3 and Figure 3. The most sustainable solution is by using Barge and the most an-susteinable solution is by Truck, as it was obtained choice parameters. 


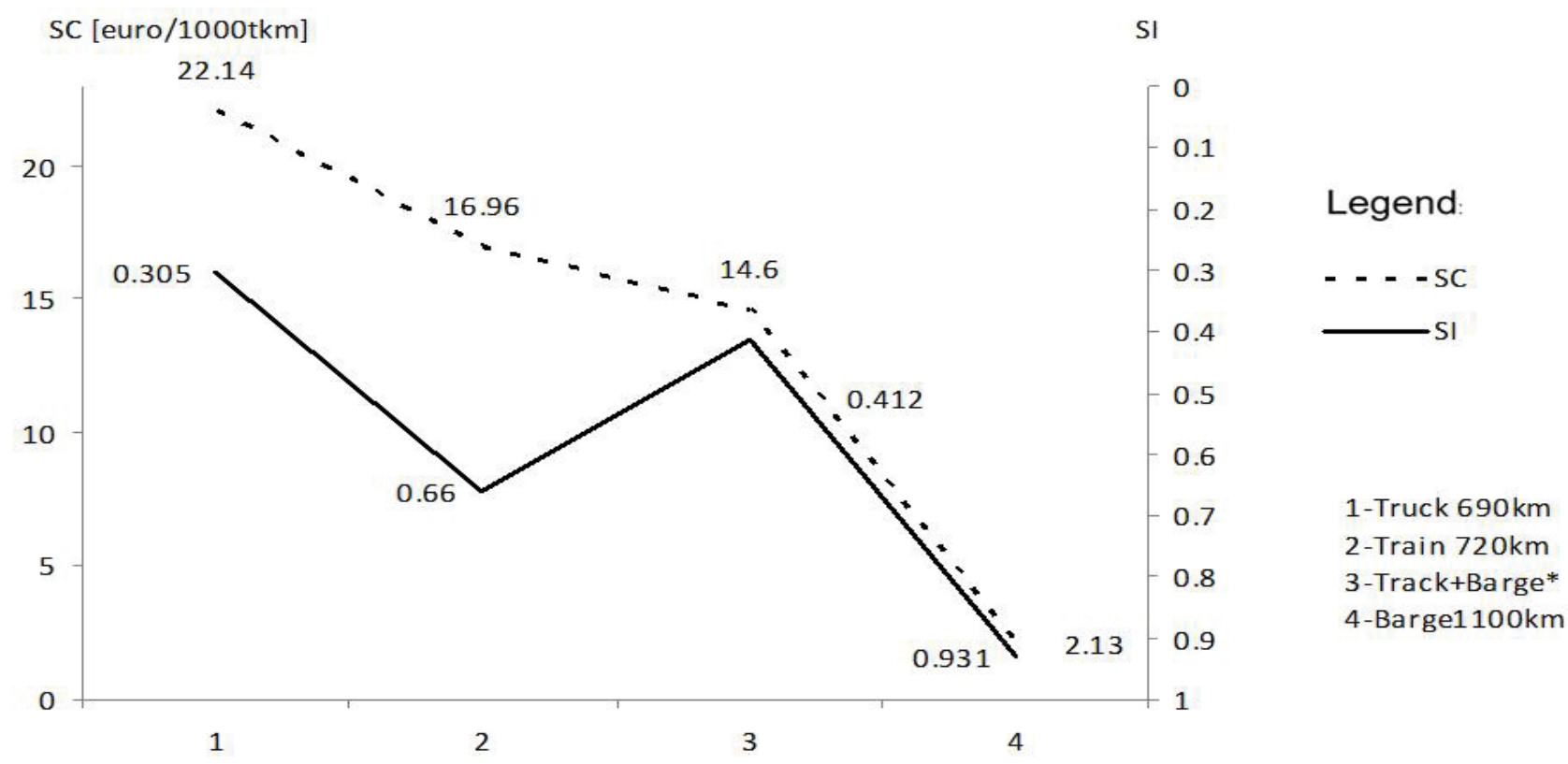

Figure 3: Sustainability for transport of prefabricated RC elements.

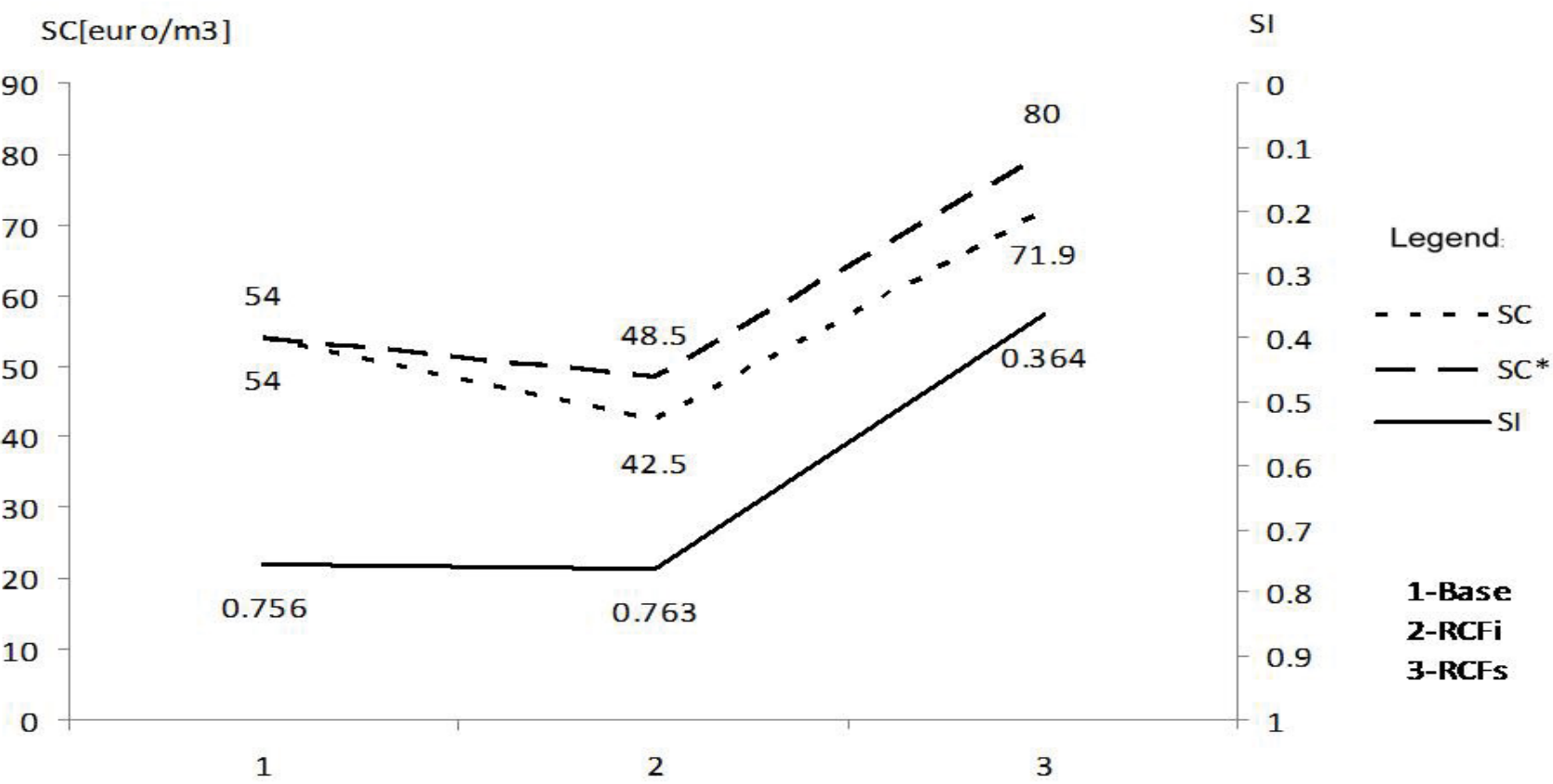

Figure 4: Sustainability for recycling concrete fines.

\section{Experimental research on recycled concrete fines (RCF)}

For the analyses of the sustainability of recycling materials, the batches taken into account are: the reference mixture without recycling substitution (Ref): the batch with $30 \%$ replacement of cement by initial concrete finest (RCFi); the sample with $45 \%$ replacement of sieved concrete finest (RCFs). The RCF was obtained after crushing a C 16/20 concrete beam. The crushing of the concrete sample was performed 90 days subsequent to the casting. The mortar was prepared using Portland cement CEM I $52.5 \mathrm{R}$. The mortar mixtures are presented in Table 4 [25-27].

From Table 5 and Figure 4 it can be concluded: the most sustainable solution proved to be RCFi - the batch with $30 \%$ replacement of cement 


\begin{tabular}{|c|c|c|c|c|c|c|c|c|}
\hline \multirow[t]{2}{*}{ Parameters } & \multirow{2}{*}{$\alpha, \beta, y$} & \multicolumn{4}{|c|}{ Sustainability index for rehabilitation solution, SI } & \multicolumn{3}{|c|}{$\begin{array}{l}\text { Sustainability cost for rehabilitation } \\
\text { solution, SC }\end{array}$} \\
\hline & & Steel profiles & RC jacketing & CFRP & Reference & Steel profiles & RC jacketing & CFRP \\
\hline 1 & 2 & 3 & 4 & 5 & 6 & 7 & 8 & 9 \\
\hline $\mathrm{CO}_{2}$ emissions, $\mathrm{E}[\mathrm{kg} / \mathrm{m} 2]$ & 0.4 & 41.7 & 93.1 & 25.47 & 25.47 & 9.59 & 21.41 & 5.86 \\
\hline Cost, $\mathrm{C}\left[€ / \mathrm{m}^{2}\right]$ & 0.2 & 91.66 & 68.4 & 155.7 & 68.4 & 91.66 & 68.4 & 155.7 \\
\hline Workload, W [man.hour/m²] & 0.1 & 4.29 & 5.9 & 1.86 & 1.9 & 42.9 & 59 & 18.6 \\
\hline \multirow{2}{*}{ Increase of bending moment, $\Delta \mathrm{B}\left[\mathrm{kNm} / \mathrm{m}^{2}\right]$} & \multirow{2}{*}{0.1} & \multirow{2}{*}{62.37} & \multirow{2}{*}{57.2} & \multirow{2}{*}{58.26} & \multirow{2}{*}{62.37} & 156 & 143 & 146 \\
\hline & & & & & & $156^{*}$ & $156^{*}$ & $156^{*}$ \\
\hline \multirow{2}{*}{ Increase of stiffness, $\Delta \mathrm{K}\left[\mathrm{kNm} / \mathrm{m}^{2}\right]$} & \multirow{2}{*}{0.2} & \multirow{2}{*}{241.61} & \multirow{2}{*}{292.6} & \multirow{2}{*}{169.1} & \multirow{2}{*}{292.62} & 205 & 248.7 & 143.8 \\
\hline & & & & & & $248.7^{*}$ & $248.7^{\star}$ & $248.7^{*}$ \\
\hline \multirow{2}{*}{ Sustainability, SI/SC } & \multirow{2}{*}{--} & \multirow{2}{*}{0.702} & \multirow{2}{*}{0.633} & \multirow{2}{*}{0.797} & \multirow{2}{*}{1} & 83 & 92.2 & 78.7 \\
\hline & & & & & & $91.7^{*}$ & $93.5^{*}$ & $100.6^{*}$ \\
\hline
\end{tabular}

'The final value $[€]$ of: Bending moment $\triangle B C$, stiffness $\Delta K C$ and sustainability costs $€ C$ (see formula 6 )

Table 2: Rehabilitation of the Western University of Timisoara.

\begin{tabular}{|c|c|c|c|c|c|c|c|c|c|}
\hline \multirow[b]{2}{*}{ Parameters } & \multicolumn{5}{|c|}{ Sustainability index for transportation by } & \multicolumn{4}{|c|}{ Sustainability costs for transportation by } \\
\hline & $\begin{array}{c}\text { Truck } 690 \\
\text { km }\end{array}$ & $\begin{array}{c}\text { Train } 720 \\
\text { km }\end{array}$ & Track+Barge* & $\begin{array}{c}\text { Barge } \\
1100 \mathrm{~km}\end{array}$ & Ref. & $\begin{array}{c}\text { Truck } 690 \\
\text { km }\end{array}$ & $\begin{array}{c}\text { Train } 720 \\
\text { km }\end{array}$ & Track+Barge* & Barge 1100 km \\
\hline 1 & 2 & 3 & 4 & 5 & 6 & 7 & 8 & 9 & 10 \\
\hline $\begin{array}{l}\mathrm{CO}_{2} \text { emissions, } \\
\mathrm{E} \mathrm{kg/1000} \mathrm{tkm}\end{array}$ & 123.13 & 24 & 46.14 & 22.43 & 22.4 & 28.32 & 5.52 & 10.61 & 5.16 \\
\hline $\begin{array}{l}\text { Cost, C } \\
€ / 1000 \mathrm{tkm}\end{array}$ & 39.4 & 56.04 & 35.26 & 0.04 & 0.04 & 39.4 & 56.04 & 35.26 & 0.04 \\
\hline $\begin{array}{l}\text { Duration, Du } \\
\text { hour/1000 tkm }\end{array}$ & 0.11 & 0.12 & 0.3 & 0.31 & 0.11 & 2.2 & 2.4 & 6 & 6.2 \\
\hline $\begin{array}{l}\text { Dust, D } \\
\mathrm{g} / 1000 \mathrm{tkm}\end{array}$ & 0.13 & 0.04 & 0.06 & 0.04 & 0.04 & 0.12 & 0.04 & 0.06 & 0.04 \\
\hline $\begin{array}{c}\text { Noise, } N \\
\mathrm{~dB}\end{array}$ & 90 & 110 & 90 & 50 & 50 & 13.5 & 16.5 & 13.5 & 7.5 \\
\hline $\begin{array}{l}\text { Sustainability } \\
\text { SI/SC }\end{array}$ & 0.305 & 0.66 & 0.412 & 0.931 & 1 & 22.14 & 16.96 & 14.6 & 2.13 \\
\hline
\end{tabular}

Notes: 'Track $150 \mathrm{~km}+$ Barge $950 \mathrm{~km} \mathrm{\alpha ,} \beta, \mathrm{\gamma}$-the same as in Table 2

Table 3: Transport of prefabricated RC elements.

\begin{tabular}{|c|c|c|c|c|c|c|}
\hline \multirow{2}{*}{ Mortar mixture } & \multicolumn{3}{|c|}{ Binder } & \multirow{2}{*}{ Sand \% } & \multirow{2}{*}{ Water \% } & \multirow{2}{*}{ Compressive strength $\mathrm{N} / \mathrm{mm}^{2}$} \\
\hline & CEM I \% & $\mathrm{RCF}<1 \mathrm{~mm}, \%$ & RCF sieved $<63 \mu \mathrm{m}, \%$ & & & \\
\hline 1 & 2 & 3 & 4 & 5 & 6 & 7 \\
\hline Base & 22 & 0 & 0 & 67 & 11 & 52.5 \\
\hline $\mathrm{RCFi}$ & 15.4 & 6.6 & 0 & 67 & 11 & 31 \\
\hline RCFs & 12.1 & 0 & 9.9 & 67 & 11 & 25 \\
\hline
\end{tabular}

Table 4: Mortar mixture and compressive strength.

\begin{tabular}{|c|c|c|c|c|c|c|c|c|}
\hline \multirow{2}{*}{ Parameters } & \multirow{2}{*}{$\alpha, \beta, \gamma$} & \multicolumn{4}{|c|}{ Sustainability Index for mixtures } & \multicolumn{3}{|c|}{ Sustainability costs for mixtures } \\
\hline & & Base & RCFi & RCFs & Reference & Base & RCFi & RCFs \\
\hline 1 & 2 & 3 & 4 & 5 & 6 & 7 & 8 & 9 \\
\hline $\begin{array}{c}\text { Energy, } \mathrm{E} \\
\mathrm{mJ} / \mathrm{m}^{3}\end{array}$ & 0.4 & 2104 & 1609 & 3736 & 1500 & 69.43 & 53.1 & 123.3 \\
\hline $\begin{array}{c}\text { Direct cost, C } \\
€ / \mathrm{m}^{3}\end{array}$ & 0.2 & 44 & 42 & 78 & 40 & 44 & 42 & 78 \\
\hline $\begin{array}{l}\text { Manpower,M } \\
\text { man-hour } / \mathrm{m}^{3}\end{array}$ & 0.1 & 2 & 3.5 & 5.4 & 2 & 20 & 35 & 54 \\
\hline $\begin{array}{c}\text { Waste, W } \\
\% / \mathrm{m}^{3}\end{array}$ & 0.1 & 7 & 6.9 & 20.7 & 5 & 1 & 1 & 3 \\
\hline $\begin{array}{l}\text { Dust, D } \\
\mathrm{g} / \mathrm{m}^{3}\end{array}$ & 0.05 & 15 & 17.8 & 56.2 & 14 & 1 & 1 & 1 \\
\hline $\begin{array}{c}\text { Noise, } \mathrm{N} \\
\mathrm{dB} / \mathrm{m}^{3}\end{array}$ & 0.05 & 23 & 30 & 67 & 20 & 3.45 & 4.5 & 10 \\
\hline \multirow{2}{*}{ Compressive strength, $\mathrm{N} / \mathrm{mm}^{2}$} & \multirow{2}{*}{0.1} & \multirow{2}{*}{52.5} & \multirow{2}{*}{31} & \multirow{2}{*}{25} & \multirow{2}{*}{55} & 152 & 90 & 73 \\
\hline & & & & & & $152^{*}$ & $152^{*}$ & $152^{*}$ \\
\hline Sustainability & -- & -- & -- & -- & -- & 54 & 42.5 & 71.9 \\
\hline $\begin{array}{c}\text { Index SI/costs } \\
\text { SC }\end{array}$ & -- & 0.76 & 0.763 & 0.364 & 1 & $54.0^{*}$ & $48.5^{*}$ & $80.0^{*}$ \\
\hline
\end{tabular}

Table 5: Sustainability of recycled concrete fines. 
by initial concrete finest; the sample with $45 \%$ replacement of sieved concrete finest, RCFs, is the most unsustainable due to of unfavourable parameters as direct cost, manpower, waste, dust, noise and compressive strength.

\section{Discussions and Conclusions}

Using of the new approach for the specific construction works sustainability model some advantages are obtained.

1. The judgement of the sustainability by using of the price of each parameter and finally of the sustainability cost is easier understandably by specialists: the most sustainable solution is the cheapest one.

2. By introduction of the correction of the mechanical characteristics (bending moment, stress and stiffness) the better result of the sustainability is obtained: for the rehabilitation of the Western University Timisoara the coating with CFRP is the most sustainable by analyses with SI and SC (Table 2 and Figure 2) but without assuring the drift limitation condition; after operating the correction of the mechanical characteristics, the most sustainable solution is by using steel profiles, which has been used.

3. Costs of main parameters were taken from Romanian practice. For different zones and countries, specific costs will have to be used.

\section{References}

1. BRE Global (2009) BRE Environmental and Sustainability Standard BES. BRE Global, Wattford, England.

2. US Green Building Council (2009) LEED 2009 for New Construction and Major Renovations. USGBC, Washington DC.

3. German Sustainable Building Council (2009) German sustainable building certificate: Structure, application, criteria, second english edition. DGNB

4. CASBEE for New Construction. Technical Manual (2010) Japan Sustainable Building Consortium (JSBC).

5. Larsson N (2011) SB method and SB tool for 2011 - Overview.

6. Green Building Council of Australia (GBCA) (2009) Green star overview, certification. GBCA, Sydney.

7. HK-BEAM Society (2004) HK-BEAM 4/04 new buildings. User Manual.

8. ISO 15392 (2008) Sustainability in building construction- General principles. ISO.

9. ISO 21931-1 (2010) Building construction-sustainability in building constructionframework for methods of assessment for environmental performance of construction works. ISO.
10. ISO 21929-1 (2011) Building construction-sustainability in building constructionsustainability indicators-part 1-framework for development of indicators for buildings -abstract. ISO.

11. BS EN 15643-1 (2010) Sustainability of construction works. Sustainability assessment of buildings. general framework. European Committee for Standardization.

12. BS EN 15978 (2011) Sustainability of construction works-assessment of environmental performance of buildings-calculation method. European Committee for Standardization.

13. Bob L, Bob C (2010) Sustainability of new buildings and strengthened structures. $9^{\text {th }}$ International Conference for Highrise Towers and Tall buildings, Münich.

14. Bob C, Dencsak T (2010) Building sustainability- civil engineer approach. Lambert Academic Publishimg, Saarbrücken.

15. Bob C, Dencsak T, Bob L (2010) Sustainability of buildings. Proc $4^{\text {th }}$ WSEAS International Conference Tunisia.

16. Ding GKC (2007) Sustainable construction: The role of environmental assessment tools. J Environ Manage 86: 451-464.

17. Diaz-Balteiro L, Romero C (2004) In search of a natural systems sustainability index. Ecol Econ 49: 401-405.

18. Matos IC, Neves L, Goncalves B (2015) Asset management. IABSE, Structural Engineering Documents.

19. ASTME 17-83 (1983) Standard practice for measuring life-cycle costs of buildings and building Systems. American Society for Testing and Materials.

20. Tsimplokoukou K., Lamperti M., Negro P (2014) Building design for safety and sustainability. JRC Science and Policy Reports, European Commission.

21. Bob C, Dencsak T (2012) RC structures a solution for sustainable development. IABSE Symposium Report 98: 9-16.

22. Dencsak T, Bob C, lures $L$ (2012) Sustainability evaluation of construction works using original model. international multidisciplinary scientific geo-conference: SGEM: Surveying geology and mining ecology management 5: 833 .

23. Bob C, Dencsak T, Bob L (2014) A sustainability model for the assessment of civil engineer works. Recent advances in energy, environment, biology and ecology, proceedings of the 10th WSEAS International Conference on EEESD 114

24. Dencsak T, Bob C (2012) Rating tools for the evaluation of building sustainability. Proc IALCCE, Vienna.

25. Bob C, Chendes R, Dan S (2017) Experimental Research on Recycled Concrete Aggregate (RCA). SFJGW 1.

26. Khatib J (2016) Sustainability of construction materials. $2^{\text {nd }}$ Edition, Elsevier Woodhead Publishing.

27. Chendes RV (2017) Experimental determination for construction recycling (in Romanian) Ph.D.Thesis, Politehnica University of Timisoara. 